\title{
IMPACTS OF COMPUTERIZATION AND DIGITIZATION: SOME HEALTH ISSUES
}

\author{
László Berényi ${ }^{1}$ and Péter László Sasvári ${ }^{2}$
}

DOI: $10.24989 /$ ocg.338.18

\begin{abstract}
Computerization and digitization are effects and the engines of development at the same time. Computers surround both work activities and beyond. There are several benefits available, including the faster, easier, and cheaper way of managing our tasks. However, there are undesirable health impacts to consider, but these are less pronounced. Exploring these impacts and preventing the occurrence is essential for improving the efficiency of computerization.
\end{abstract}

The study focuses on the effects of computer work by analyzing its exhausting characteristics and the tiredness or pain in different body parts. The research method uses a survey of full-time and parttime higher education students. The sample consists of 200 randomly selected responses collected between 2018 and 2019. It allows analyzing the differences of perceptions between respondents with and without job experience. Beyond descriptive statistics, ANOVA and correlation analysis was conducted for exploring the relations. Data analysis was supported by IBM SPSS version 25.

The results show that the perceived undesirable health impacts are timeless and ageless. Eye-related problems, as well as back and shoulder, are considered the most critical by the respondents. The main implication of the study is that more attention must be paid to the field, appearing in regulations and developing training programs for computer users. The results presented in this paper aim to highlight the importance of the prevention of harmful symptoms of computer work, which are not in the mainstream right now.

\section{Introduction}

Digitization surrounds everyday life, including public administration. Both the diffusion of on-line services and mobile access to them has spread explosively. A detailed analysis of the development goes far beyond the scope of this study. The goal of the study is to draw attention to a seemingly less critical impact of the field, the health impact of exposure to computer work, especially the right sitting posture.

Jakob and Krcmar [13] mention digitization as a buzzword that intertwines with both the business and the public sector. However, there hinder factors of digitization due to its complexity. The maturity models in the field [12] takes several factors into account, focusing on technological, organizational, leadership issues, as well as the capability to the required changes in the systems [12], [13].

\footnotetext{
${ }^{1}$ National University of Public Service, Department of Public Organization and Information Technology, H1083 Budapest, Ludovika square 2., Hungary, berenyi.laszlo@uni-nke.hu

${ }^{2}$ National University of Public Service, Department of Public Organization and Information Technology, H1083 Budapest, Ludovika square 2., Hungary, sasvari.peter@uni-nke.hu
} 
The historical review of governmental transformation by Paulin [21] evidently pointed out that (public) administration and management are already unimaginable without computer work. Efficiency has been an essential factor for years, like capability improvement and cost savings [9]. The development and the recent spread of the technology redraw the content of these factors (e.g., big data, mobile devices, prompt administration), but the fundamental challenge remains.

According to the scope of this study, the availability of the technological background is not a limitation of effective computer activities. This presumption is confirmed by the data of the Hungarian Central Statistical Office (Table 1). The spread of computers and related services is remarkable in the previous ten years. There were 223514 computers used in public administration, defense, and compulsory social security in 2005; it was increased to 305928 in 2013. The number of servers increased by $45 \%$ during this period.

\begin{tabular}{rlllll}
\hline Item & $\mathbf{2 0 0 9}$ & $\mathbf{2 0 1 1}$ & $\mathbf{2 0 1 3}$ & $\mathbf{2 0 1 5}$ & $\mathbf{2 0 1 7}$ \\
\hline Computer & 99.7 & 99.3 & 100.0 & 99.6 & 100.0 \\
\hline Internet & 98.9 & 98.3 & 99.6 & 99.6 & 99.4 \\
\hline E-mail & 98.1 & 98.1 & 98.3 & 98.6 & 99.2 \\
\hline Web page &.. & 58.0 & 80.9 & 84.3 & 87.9 \\
\hline Intranet & 17.3 & 16.7 & 21.8 & 27.5 & 27.9 \\
\hline Social media tools &.. &.. &.. & 36.5 & 43.0 \\
\hline Table 1: Use of information and communication tools in public administration, \\
defense and compulsory social security (\%) [16]
\end{tabular}

On the other side, the utilization of internet-based administration of businesses has been increasing (Table 2). Of course, it should not be ignored that a considerable effort and several years of coordinated work were required by IT experts, policymakers, public administration experts, teachers, and other participants of the development projects. The progress is explained in [5] and [6] in detail.

\begin{tabular}{rllllllll}
\hline Item & $\mathbf{2 0 0 9}$ & $\mathbf{2 0 1 0}$ & $\mathbf{2 0 1 1}$ & $\mathbf{2 0 1 2}$ & $\mathbf{2 0 1 4}$ & $\mathbf{2 0 1 5}$ & $\mathbf{2 0 1 6}$ & $\mathbf{2 0 1 7}$ \\
\hline Obtaining information & 77.3 & 93.0 & 93.8 & 94.9 & 91.3 & 93.2 & 92.9 & 91.6 \\
\hline Download forms & 76.8 & 88.8 & 89.9 & 93.1 & 89.4 & 90.9 & 91.4 & 90.1 \\
\hline $\begin{array}{r}\text { Submitting completed } \\
\text { forms }\end{array}$ & 69.5 & 82.9 & 84.5 & 91.4 & 87.9 & 89.3 & 90.1 & 89.2 \\
\hline $\begin{array}{r}\text { Fully electronic } \\
\text { management of } \\
\text { administrative }\end{array}$ & 44.0 & 50.9 & 77.5 & 86.3 & 83.7 & 84.8 & 86.1 & 84.9 \\
$\begin{array}{c}\text { pdocedures (including } \\
\text { payments) }\end{array}$ & & & & & & & &
\end{tabular}

Table 2: Use of the Internet to handle administrative matters in proportion to businesses using the Internet [16]

Literature in the field focuses on the tasks and processes managed by the computers but gives less attention to the physical factors of the work environment. Of course, the man is involved in the factors, but ergonomic aspects, especially the long-term impacts, have a lower emphasis. While the benefits of computerization and digitization seem greatly exceeding the risks both on macro and micro levels, including but not limited to the labor market [23], education [20], or digital inequality [7], [8], the physical impacts on the human body must be considered. Unfavorable health impacts, which are the results of doing the activities sitting in front of a computer, lead to a reduction in the working capacity. 
A relevant difficulty in analyzing the phenomena is that both working and free time activities are increasingly dependent on computers, and the health impacts are independent of the purpose of the activities. All these seem to be marginal issues of digitization until disruptions due to illness do not endanger work processes.

Intensified computer work leads to increased load in the musculoskeletal system, in the eyes, and mental well-being also can be influenced [19]. These can be considered as risks of computerization. Managing human-computer interactions requires a comprehensive approach, including ergonomic issues. Computer vision syndrome (CVS) covers the most symptoms, but it focuses mainly on ocularrelated problems [2], [10], [29], [30]. According to the workplace design for computer activities (see [14], [31], [32]), other factors may be included. Moreover, developing healthy workplaces requires a more sophisticated approach [26], [28].

The proper sitting posture, selection of tools, schedule lead together to both desirable and undesirable impacts. Feeling discomfort and declining performance are the first signs, health problems, workplace leaving can be the outcome, moreover, missed opportunities of the development can be the impact.

\section{Research design}

\subsection{Research goal and method}

Understanding the impacts of computer work is a critical personal issue with relevant social and economic effects [17], [22]. According to health impact, the related problems are general because computer usage is not limited to working. Especially the mobilization and smartphones show spectacular implications of addiction in everyday activities [11]. The spread of use foreshadows the appreciation of the unfavorable impacts as well.

Among others, public servants perform most of their tasks. In their case, the government and society must bear the responsibility for maintaining their health. That is not just an altruist obsession; public servants are employees who contribute to organizational performance. It is to note that the same relationship can be described in the competitive sector between employees and companies. Problems lead to reduced work performance [18], [26].

The development of the diseases caused by computer work comes over time [14]. Early identification is critical to successful corrective or preventive actions. That is the reason why the students are the focus if the investigations. There is an excellent opportunity to intervene in a timely manner for preventing the harms and disorders through education and training. Moreover, it is getting used to the right working environment for earlier than higher education studies [1], [24].

The study uses a voluntary survey that asks about exhausting feeling or hurts related to computer work (evaluated on a 6-point scale):

- $\quad$ in the eyes,

- $\quad$ in the hands and arms,

- $\quad$ in the fingers,

- $\quad$ in the back and shoulders,

- $\quad$ in the neck,

- $\quad$ in the waist,

- $\quad$ general evaluation of feeling computer work exhausting. 
The EvaSys Survey automation system supports data collection, and the data analysis is conducted with the IBM SPSS version 25.

Age, gender, and job experience are used as grouping factors. Nowadays, having a job experience is typical among full-time students, in the form of an internship, or even being part-time employed. These students meet computer work and the workplace in different ways.

This study is a contribution to this knowledge base by asking business and public administration higher education students about their experience in the health impacts of computer work. According to the survey presented in this paper, the research question can be formulated whether any unfavorable health impacts of computer work can be detected among the students. However, students cannot represent the public administration staff; this survey is an initial but essential step of a preventive program. Of course, a comprehensive solution cannot ignore the staff who have been working for a long time in the public administration since it can give an extensive situation report.

\subsection{Research sample and limitations}

The research sample of the study consists of 200 randomly selected higher education students from the 2018-2019 data collection period of a survey designed for a comprehensive analysis of the competencies and attitudes of higher education students to information technology. There are students of business, public administration, and law studying at various Hungarian higher education institutions who may be future public servants. Since a representative sample structure cannot be assured, a random selection was used for avoiding the overrepresentation of any universities or specialties.

Due to the data collection method and the voluntary nature of the survey, the interpretation of the results is limited; however, the results may be progressive. A relevant limitation of the results is that the results are based on the self-evaluation of the respondents by a voluntary survey, and not on a professional medical examination. The research can be considered as an awareness-raising pilot study in the field.

\section{Results and discussion}

\subsection{Sample consistency}

The survey and the responses are statistically tested by the usual methods used in social sciences [3], [25]. These tests have an important role in the interpretation of the results due to the convenient sampling. The reliability of the survey is passed based on the Cronbach Alpha test (value $=.825, \mathrm{n}=6$ ) for the questions about health impacts. The Kolmogorov-Smirnov test failed for the normal distribution of the answers, and the two-tailed significance is .000 for each item. Therefore, the ANOVA analysis was conducted by the Kruskal-Wallis test.

The unfavorable effect of computer work is influenced by several factors, including the level and time of exposure. Gender and work experience (with or without job experience) as grouping factors are related to this nature. Since the sample size and composition do not allow a detailed analysis by gender, a convenient splitting was applied in 1995 as the year of born.

Comparing the respondents who were born earlier than 1995 (marked as old in the indexes) and in that year or later (marked as young in the indexes), a significant difference was found in the questions 
about tiredness or pain of eyes $\left(\mathrm{x}_{\text {old }}=4.11, \mathrm{x}_{\text {young }}=3.60, \chi^{2}=4.608\right.$, sig. $\left.=.032\right)$ and general evaluation $\left(\mathrm{x}_{\text {old }}=3.55, \mathrm{x}_{\text {young }}=3.10, \chi^{2}=4.690, \mathrm{sig} .=.030\right)$. Differences by gender are significant in the case of back and shoulder $\left(\mathrm{x}_{\text {female }}=4.14, \mathrm{x}_{\text {male }}=3.53, \chi^{2}=6.586\right.$, sig. $\left.=0.010\right)$. Job experience is a significant grouping factor in the case of back and shoulder $\left(\mathrm{x}_{\text {nojob }}=3.68, \mathrm{x}_{\mathrm{job}}=4.15, \chi^{2}=4.111\right.$, sig $\left.=.043\right)$.

The correlations between the items of the survey, there are moderate but significant interrelations found. Correlation between finger-hands and arms (Spearman corr $=.604$, sig. $=.000$ ) and neck-back and shoulders (Spearman corr. $=.721$, sig. $=.000$ ) can be highlighted.

\subsection{Survey results}

Since there are few significant differences found by the grouping factors, the survey results are presented for the total sample and by job experience. Responses are measured on a 6-point scale (1: not at all, 6: often). The distribution of the responses is characterized by rather no ( 1 and 2 answers), moderate ( 3 and 4 replies), and rater yes (5 and 6 replies) labels.

$20.5 \%$ of the respondents feel computer work exhausting, and $34.5 \%$ do not think it so (Figure 1 ). Figure 2 shows the differences between the existence of the job experience of the respondents.

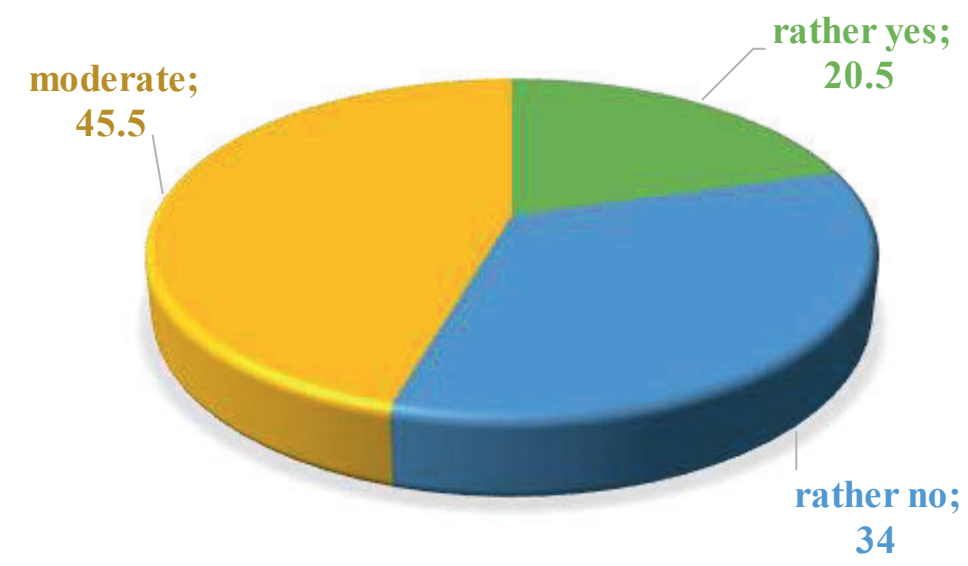

Figure 1: Do you generally feel tired when or after doing computer activities? (total sample, \% of respondents) 


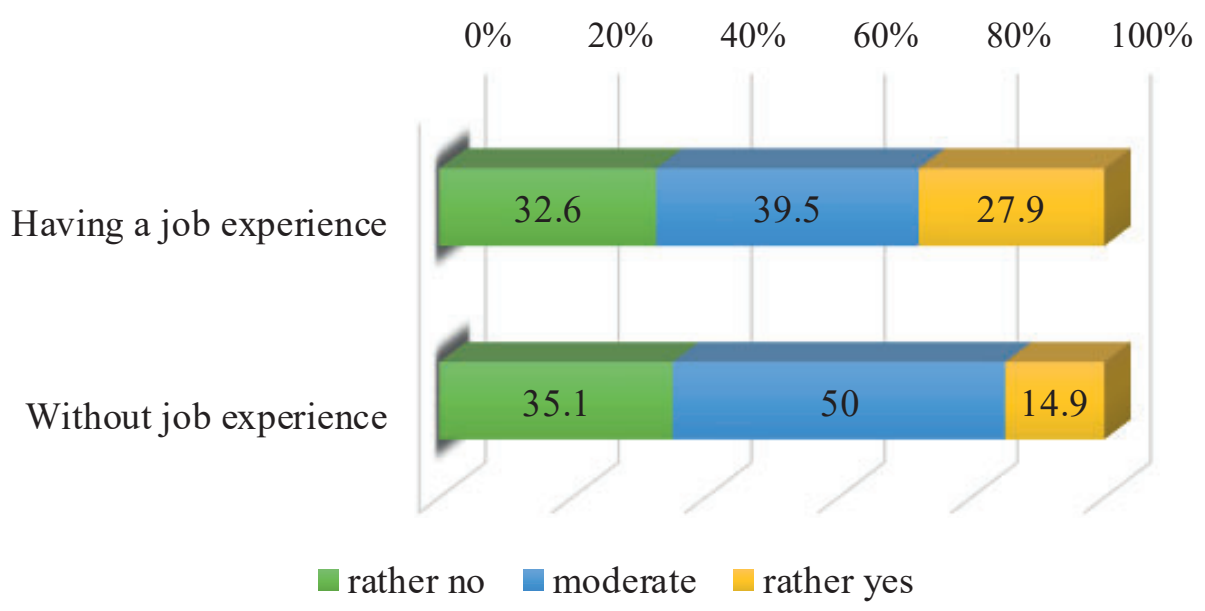

Figure 2: Do you generally feel tired when or after doing computer activities? (by job experience, \% of respondents)

Figure 3 represents the average values of the respondents' evaluations of feeling tiredness or harm in one or more body parts. The higher average value in the graph suggests that the affected body part is more critical to the health or well-being of the respondent. The differences in the values point out that there are two critical areas where the respondents feel computer work exhausting or harmful: eyes as well as back and shoulder. Both are consistent with the literature of computer vision syndrome, and there are special warning signs of ergonomics literature in this respect. The distribution of the responses confirms the results (Figure 4, Table 3).

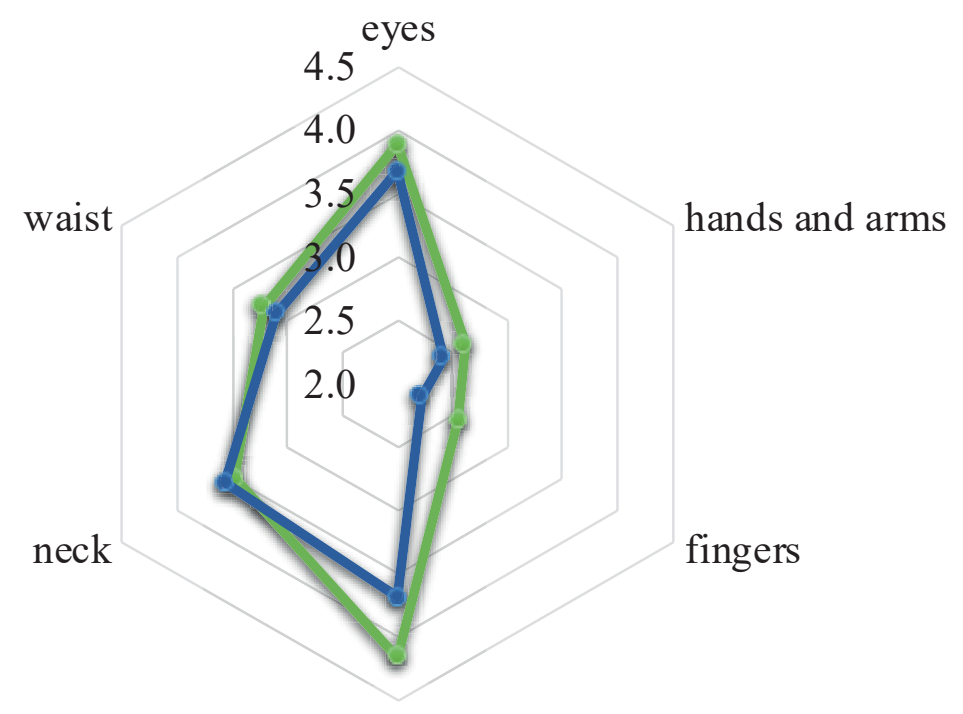

back and shoulder

- Having a job experience $\quad-$ Without job experience

Figure 3: Feeling tired or harm in some body parts related to computer work (average values, 6-point scale) 


\begin{tabular}{rcccc}
\hline & $\begin{array}{c}\text { job } \\
\text { experience }\end{array}$ & rather no & moderate & rather yes \\
\hline \multirow{2}{*}{ eyes } & no & 27.2 & 40.4 & 32.5 \\
\cline { 2 - 5 } & yes & 25.0 & 41.0 & 34.0 \\
\hline \multirow{2}{*}{ hands and arms } & no & 57.9 & 35.1 & 7.0 \\
\cline { 2 - 5 } fingers & yes & 56.5 & 32.5 & 11.0 \\
\cline { 2 - 5 } & no & 61.4 & 35.1 & 3.5 \\
\hline back and & yes & 60.0 & 31.5 & 8.5 \\
\cline { 2 - 5 } shoulders & yes & 25.4 & 38.6 & 36.0 \\
\hline \multirow{2}{*}{ neck } & no & 34.5 & 38.5 & 40.0 \\
\cline { 2 - 5 } & yes & 34.5 & 28.9 & 36.8 \\
\hline \multirow{2}{*}{ waist } & no & 43.9 & 33.3 & 22.8 \\
\cline { 2 - 5 } & yes & 41.0 & 35.5 & 23.5 \\
\hline
\end{tabular}

Table 3: Feeling tired or harm in some body parts related to computer work (\% of respondents by job experience)

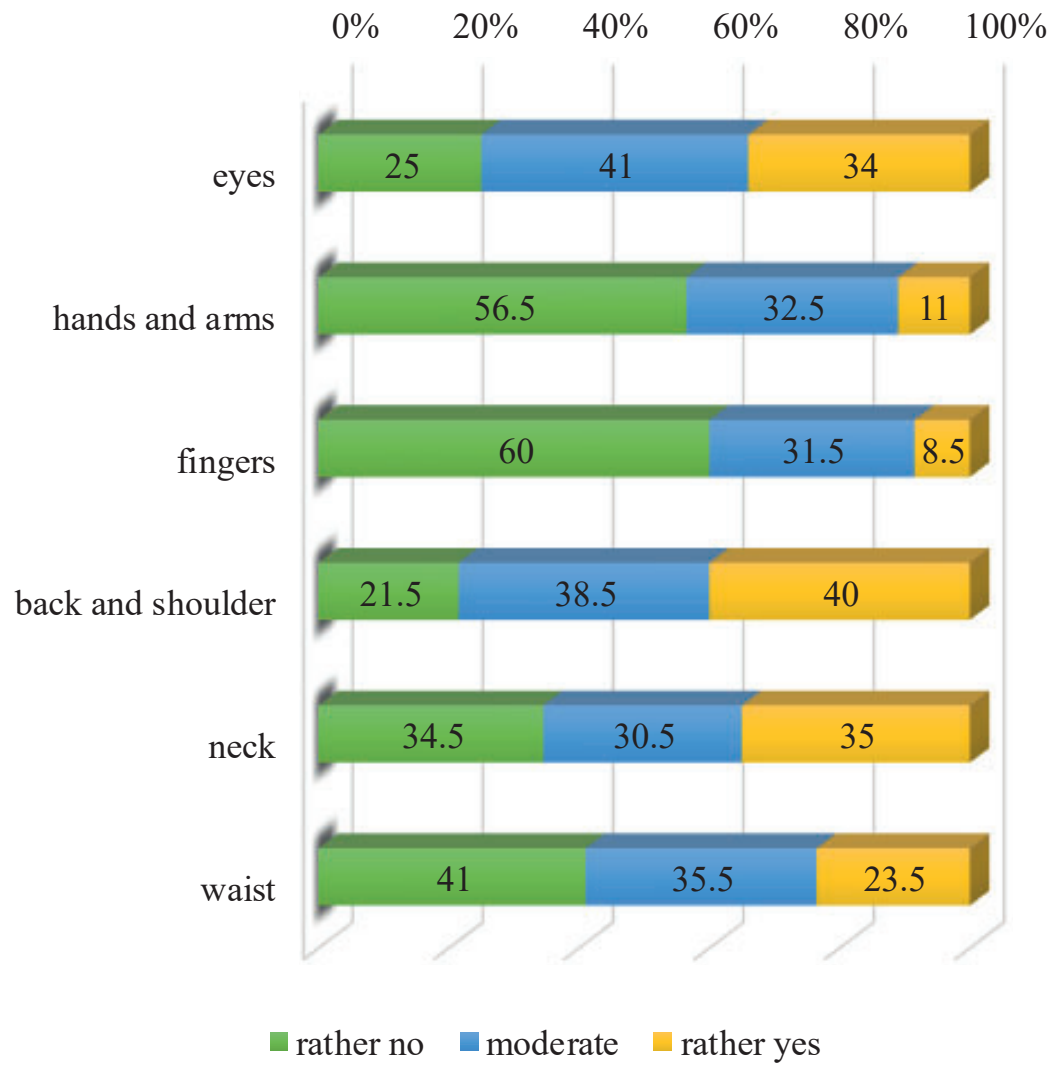

Figure 4: Feeling tired or harm in some body parts related to computer work (\% of respondents, total sample)

Fighting against the harmful effects of computer work resulted from the special sitting posture is inserting regular breaks, stretching activities, and some move. The survey included a question about 
this practice. $6 \%$ of the respondents marked that this is not common for him or her. $56 \%$ of them make a break sometimes, and $38 \%$ of them regularly. Cross-tabulation shows a significant difference $\left(\chi^{2}=20.653, \mathrm{~d}_{\mathrm{f}}=2\right.$, sig. $\left.=.000\right)$ by the job experience (Figure 5$)$. There is no significant difference by the age categories used in the study $\left(\chi^{2}=17.456, \mathrm{~d}_{\mathrm{f}}=14\right.$, sig. $\left.=.233\right)$.

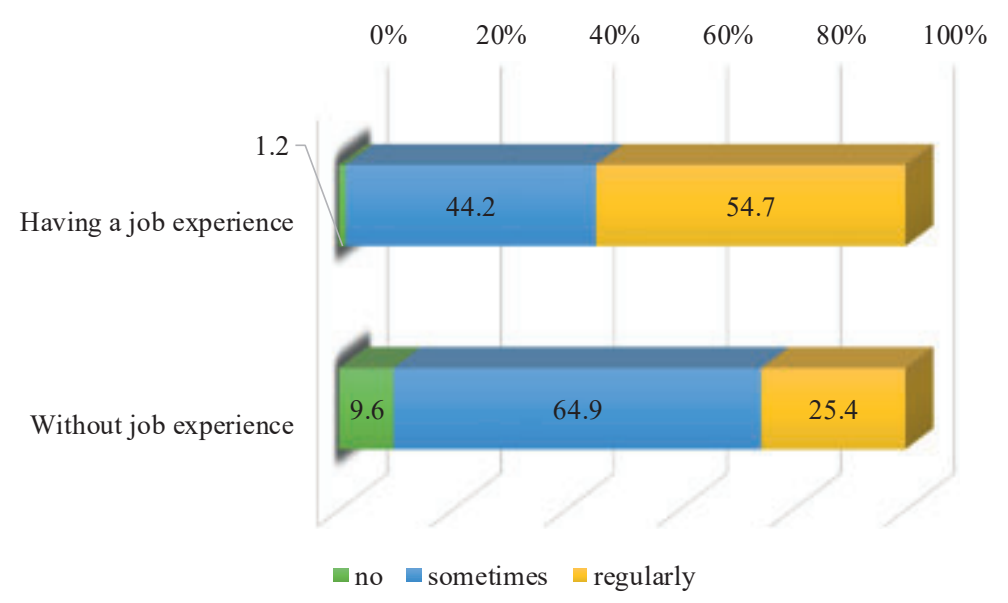

Figure 5: Having a break during computer work (\% of the respondents)

\subsection{Discussion}

The effectiveness of working with computer shall be evaluated in a comprehensive approach (Figure 6). Even there is a high-end computer available as well as an excellent IT background provided; organizational issues influence the performance. Defining the task and establishing the working environment regarding the task requirements are also conditions of the performance. Due to the flexibility of the human body to the environmental impacts, unfavorable health impacts may remain hidden for a long time. Moreover, short-term and temporary actions are against healthy solutions. Developing the working environment can be successful if task properties and the evaluation of the working environment is available. Exploring the perception of health impacts is a relevant component of the evaluation.

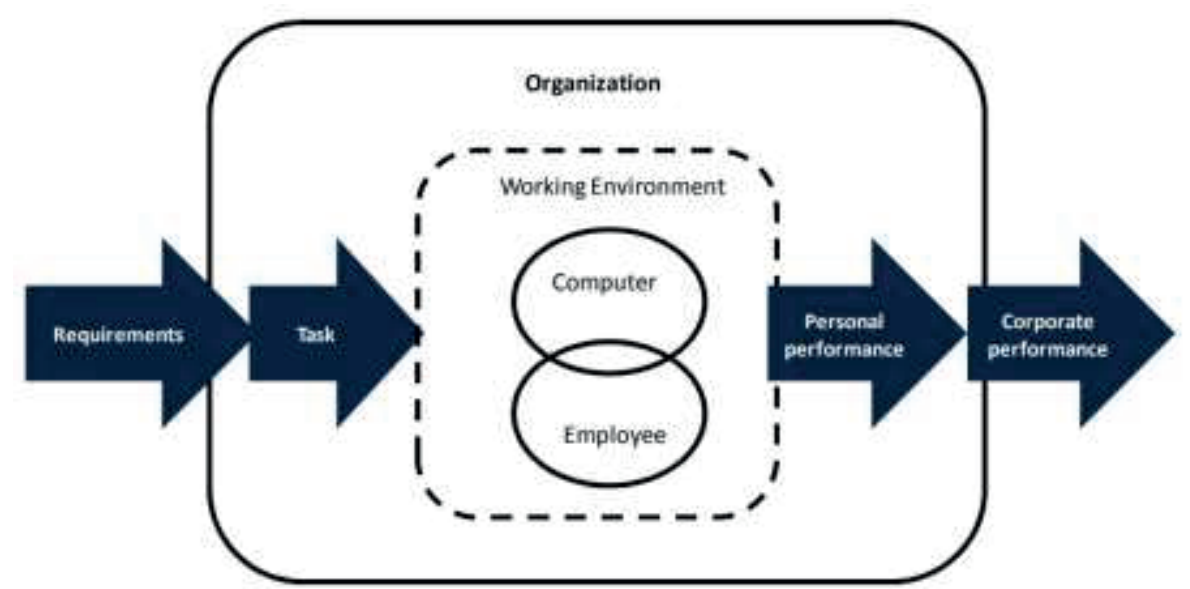

Figure 6: The role of the working environment in achieving organizational performance [4]

The survey results confirm the importance of healthcare and ergonomics professional warnings about computer work. The fact that the grouping factor shows few significant differences suggests that 
health problems of computer work are general, ageless, and timeless. Of course, this statement is valid for the sample; an extensive data collection must have the hypothesis whether it is generalizable or not. Nonetheless, the effect of job experience is perceptible based on the sample.

However, computer work is evaluated not exhausting by one-third of the total sample, the proportion of moderate and rather exhausting ratings is remarkably higher among respondents with job experience (Figure 2), and this is a warning sign. The health impacts do not depend on the purpose of the activity, and it is related to the sitting posture and exposure. Assuming that leisure and other non-job-related activities are present in the life of the respondents regardless of work, work gives extra load and stress that may lead to increased tiredness.

According to the questions about feeling tired or pain in one or more body parts, two issues stand out from the other based on both the average values and the distribution of the responses: eye, back and shoulder. A correlation analysis was conducted whether the felt tiredness or harm is limited to the gives body part of the person, or there are multiplied problems. The results confirm that the issues do not come alone. Eye problems are related to the general evaluation of feeling computer work exhausting (Spearman corr.=.577 sig.=.000). Furthermore, back and shoulders correlate with the neck (Spearman corr. $=.721$ sig. $=.000)$ and waist (Spearman corr. $=.530$ sig. $=.000$ ) problems. Paying attention to the proper sitting posture is a key issue in the related literature (see [15]); however, the design of portable computers and other devices just work against it. Making a break during the computer work is essential for reducing static strain on muscles and refreshing the skeletal system. Systematic training activities promote both preventing problems and reducing their impact [27]. Beyond the favorable physiological impacts, mental relaxation is available. Considering that the labor safety law obligates a break, the results show an unsatisfactory picture.

\section{Conclusions}

Computer work is a complex challenge. Continuous improvement of equipment, systems, and procedures allows faster and widespread access to services for work or entertainment increasingly. People spend even more time on different computers. Due to the high adaptability of the human body and mind to different environmental conditions, the negative impacts of the activities remain hidden for a long time. The prevention of the undesirable effects can be forced by the designers, but user attention is also important.

The results of the survey point out that strain on the musculoskeletal system and eyes is remarkable, regardless the age or gender in the sample. The difference in outcomes between respondents who have or do not have a job experience suggests that computer activities are considered less exhausting when it is not related to work. At the same time, negative effects perceived are not significantly smaller.

The main policy implication of the study is that more serious attention should be paid to the health impacts of computer work. The knowledge base of ergonomics must be implemented in related regulation both on local (organization) level and the legal regulation. However, the regulation of occupational health includes screen work issues, its scope is limited. Training programs may be efficient in the field. Several open questions in the field go beyond the limits of the present survey and the paper. E.g., workplace and process design require a targeted analysis among the affected people. 
It is to note that the sampling method cannot be considered representative; it is suitable for highlighting the most critical problems and designating further focus of the investigation.

\section{References}

[1] AKINBINU, T. R. and MASHALLA, Y. J., Impact of computer technology on health: Computer Vision Syndrome (CVS). Medical Practice and Review, 5(3) (2014), 20-30. https://doi.org/10.5897/MPR.2014.0121

[2] ANSHEL, J. (ed)., Visual ergonomics handbook. 2005. Boca Raton: CRC Press.

[3] BABBIE, E., The practice of social research. 2015. Boston: Cengage Learning.

[4] BERÉNYI, L., Számítógépes munkahelyek ergonómiája a gyakorlatban. Marketing \& Menedzsment. 47, 3 (2013), 76-86.

[5] BUDAI, B. B., GERENCSÉR, B. SZ. and VESZPRÉMI, B., A digitális kor hazai közigazgatási specifikumai. 2018. Budapest: Dialóg Campus Kiadó.

[6] BUDAI, B. B., KÖNIG, B., TÖRLEY, G. and ORBÁN, A., Elektronikus Közigazgatás szervezés, közigazgatási technológia. 2012. Budapest: Nemzeti Közszolgálati Egyetem.

[7] CORROCHER, N. and ORDANINI, A., Measuring the digital divide: a framework for the analysis of cross-country differences. Journal of Information Technology. 17 (2002), 9-19.

[8] EVANGELISTA, R., GUERRIERI, P. and MELICIANI, V., The economic impact of digital technologies in Europe. Economics of Innovation and New Technology. 23, 8 (2014), 802-824, http://dx.doi.org/10.1080/10438599.2014.918438

[9] FOSS, T. C., Computer Applications in Public Administration: Increased Capability at lower cost. Social Science Microcomputer Review. 5, 4 (1987), 506-513.

[10] GOWRISANKARAN, S. and SHEEDY, J. E., Computer vision syndrome: A review. Work. 52 (2015), 303-314. https://doi.org/10.3233/WOR-152162

[11] HAUG, S., CASTRO, R. P., KWON, M., FILLER, A., KOWATSCH, T. and SCHAUB, M. P., Smartphone use and smartphone addiction among young people in Switzerlan. Journal of Behavioral Addictions, 4(4) (2015), 299-307. https://doi.org/10.1556/2006.4.2015.037

[12] HUMMEL, K. and SCHENK, B., Digital maturity in the administration of a university of applied sciences. In: Nemeslaki, A., Prosser, A., Scola, D., Szádeczky, T. (eds.). Proceedings of the Central and Eastern European E|Dem and E|Gov Days, May 2-3, 2019. Facultas Verlagsund Buchhandels AG, 2019, Wien, Austria, 307-318, DOI 10.24989/ocg.v335.25

[13] JAKOB, M. and KRCMAR, H., Which barriers hinder a successful digital transformation in small and medium-sized municipalities in a federal system? In: Hansen, H., Müller-Török, R., Nemeslaki, A., Prosser, A., Scola, D., Szádeczky, T. (eds.). Central and Eastern European e|Dem ${ }_{\text {and }} \mid$ Gov Days 2018: Conference proceedings. Facultas Verlags- und Buchhandels AG, 2018, Wien, Austria, 141-150, DOI 10.24989/ocg.v331.12 
[14] KROEMER, K. and KROEMER, A., Office ergonomics. 2001. London: Taylor \& Francis.

[15] KROEMER, K., KROEMER, H. and KROEMER-ELBERT, K., Ergonomics. How to design for ease and efficiency. 2001. London: Prentice-Hall.

[16] KSH (2019): Gazdasági adatok. Információ, kommunikáció. Available at: https://www.ksh.hu/stadat_eves_4_7. Accessed: 02.11.2019.

[17] KUDRYAVTSEV M. D., KRAMIDA I. E. and IERMAKOV S. S., Influence of studying in higher educational establishment on students' harmful computer habits. Physical Education of Students, 5 (2016), 17-23. https://do.org/10.15561/20755279.2016.0503

[18] MAdElEine, P., VAngSGaARd, S., ANDERSEN, J. H., GE, H. Y. and ARENDTNIELSEN, L., Computer work and self-reported variables on anthropometrics, computer usage, work ability, productivity, pain, and physical activity. BMC Musculoskeletal Disorders, 14 (2013), 226. https://doi.org/10.1186/1471-2474-14-226

[19] MCKEOWN, C., Office ergonomics. Practical applications. 2008. Boca Raton: CRC Press.

[20] MÜLLER-TÖRÖK, R., PROSSER, A. and SCHENK, B., Digitisation and system integration in the public sector - Consequences for teaching. In: Nemeslaki, A., Prosser, A., Scola, D., Szádeczky, T. (eds.). Proceedings of the Central and Eastern European E $\mid$ Dem and E $\mid$ Gov Days, May 2-3, 2019. Facultas Verlags- und Buchhandels AG, 2019, Wien, Austria, 189-198, DOI 10.24989/ocg.v335.15

[21] PAULIN, A., Digitalisation vs. Informatisation: Different Approaches to Governance Transformation. In: Hansen, H., Müller-Török, R., Nemeslaki, A., Prosser, A., Scola, D., Szádeczky, T. (eds.). Central and Eastern European e|Dem, and e|Gov Days 2018: Conference proceedings. Facultas Verlags- und Buchhandels AG, 2018, Wien, Austria, 251-262, DOI 10.24989/ocg.v331.21

[22] SHIVENDU, S. and ZHANG, R. A., The Impact of Digitization on Content Markets: Prices, Profit, and Social Welfare. MIS Quarterly, In Press, available online: https://ssrn.com/abstract=3367395

[23] SIEVERING, O., Effects of digitalization on the labor market in Baden-Wuerttemberg. In: Hansen, H., Müller-Török, R., Nemeslaki, A., Prosser, A., Scola, D., Szádeczky, T. (eds.). Central and Eastern European e|Dem ${ }_{c}$ and e|Gov Days 2018: Conference proceedings. Facultas Verlags- und Buchhandels AG, 2018, Wien, Austria, 469-478, DOI 10.24989/ocg.v331.39

[24] SINGH, S. and WADHWA, J., Impact of computer workstation design on health of the users. Journal of Human Ecology, 20(3) (2006) 165-170. https://doi.org/10.1080/09709274.2006. 11905922

[25] STOCKEMER, D., Quantitative Methods for the Social Sciences: A Practical introduction with examples in SPSS and Stata. 2018. Berlin: Springer.

[26] SZOLNOKI, B., Egészségfejlesztéshez kapcsolódó szervezeti döntések támogatása a 4C modellel. Magyar Minőség. 28, 1 (2019), 9-13. 
[27] SZOLNOKI, B., Egyéni szinten megvalósuló egészségtámogatás. Munka után még edzés? In: Köszegi, I. R. (ed.). III. Gazdálkodás és Menedzsment Tudományos Konferencia: Versenyképesség és innováció, Neumann János Egyetem, 2019, Kecskemét, Hungary, 865871.

[28] SZOLNOKI, B., Mit tehet a foglalkoztató a mozgásszegény életmód ellen? In: Bodzás, S., Antal, T. (eds) Müszaki tudomány az észak-kelet magyarországi régióban, 2019. Debreceni Akadémiai Bizottság Müszaki Szakbizottsága, 2019, Debrecen, Hungary, 373-376.

[29] TEO, C., GIFFARD, P., JOHNSTON, V. and TRELEAVEN, J., Computer vision symptoms in people with and without neck pain. Applied Ergonomics, 80 (2019), 50-56. https://doi.org/10.1016/j.apergo.2019.04.010

[30] TURGUT, B., Ocular Ergonomics for the Computer Vision Syndrome. Journal of Eye and Vision. 1, 1-2 (2018) 1-2.

[31] WOODSON, W. E. and CONOVER, D. W., Human Engineering Guide for Equipment Designers. 1973. Berkeley: University Press.

[32] YANG, H. B., GUANG, S. S. and FENG, Y. T., Health office chair design based on ergonomics, Applied Mechanics and Materials. 274 (2013), 517-522. https://doi.org/10.4028/ www.scientific.net/AMM.274.517 